\title{
Guanajuato: A Struggle to Control Oil Theft
}

\author{
Gerardo Reyes GUZMÁN ${ }^{1 \oplus}$ - Abraham Sánchez \\ RUíz ${ }^{\circ}$ - Perla Esperanza ROSTRO HERNÁNDEZ ${ }^{3}$
}

\begin{abstract}
Guanajuato became Mexico's most dangerous entity in 2019. It used to be a peaceful state in the 1990s, but with the evolution of criminal groups and organised crime, Guanajuato became a strategic region because of its geographical location, road network, economic development and fuel pipelines. The aim of this paper is to identify the factors that brought Guanajuato to the first place in terms of homicides in 2019 nationwide. The hypothesis states that violence in the entity was the result of an invasion of the CJNG and its fight against the CSRL to dominate the theft of gasoline. To prove this hypothesis, we use a multiple regression model to correlate homicides taking place from 2015 to 2019 between the most dangerous municipalities of Guanajuato with those occurring in Jalisco and Michoacán. The correlation parameters which also take into account the road network were significant for Leon, (Guanajuato) vs. San Pedro de Tlaquepaque (Jalisco), Tlajomulco de Zúñiga (Jalisco), Tonalá (Jalisco), Zamora (Michoacán) and El Salto (Jalisco); Irapuato vs. Guadalajara (Jalisco) and San Pedro de Tlaquepaque (Jalisco) and Salamanca vs. Guadalajara (Jalisco), Tonalá (Jalisco), Zamora (Michoacán) and Lagos de Moreno (Jalisco).
\end{abstract}

Keywords: Guanajuato, violence, oil theft, GJNG, CSRL

\section{Introduction}

According to the former director of the Mexican Ministry of Public Security Alfonso Durazo Montaño, the number of homicides in Mexico diminished from January to November 2019 making hitherto a total of 31,688. However, the most dangerous federal states in terms of homicides were: Guanajuato 3,211; Baja California: 2,567; Estado de

PhD in Economics, University of Rostock, Germany, University of La Salle Bajío, Mexico, Campus Salamanca; e-mail: gerardoreyesguzman@gmail.com

$2 \mathrm{PhD}$ in Social Science, Autonomous University of Hidalgo, Mexico; University of La Salle Bajío, Mexico, Campus Salamanca; e-mail: asanchez@delasalle.edu.mx

3 Master in Fiscal Law, University of Guanajuato, Mexico; Master in Educational Administration University of La Salle Bajío, Mexico; e-mail: prostro@delasalle.edu.mx 
México: 2,603; Jalisco: 2,465 and Chihuahua: 2,379. ${ }^{4}$ Guanajuato used to be a peaceful federal state with 5 homicides per 100,000 inhabitants in 2008; then it took off to 13 in

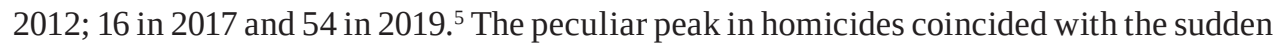
increase in the price of gasoline in 2017. The price per litre went from $15.5 \mathrm{MXN}$ in June 2017 to $19.34 \mathrm{MXN}$ in November 2018, a spike of $24.7 \% .^{6}$ The theft of gasoline soared by that time in several regions in Mexico, but particularly in Salamanca, Guanajuato, because of the refinery operating there and the vast number of pipelines installed in its underground surroundings. Thus, oil theft, also dubbed as "Huachicol”, turned into a high profitable business for organised crime. In Guanajuato, a criminal organisation named Cartel Santa Rosa de Lima (CSRL) emerged under the leadership of José Antonio Yepes, whose nickname is “El Marro", (detained by the authorities on 2 August 2020). The CSRL has been fighting the Cartel Jalisco Nueva Generación (CLNG) for several years. This warfare has taken place in Guanajuato and has already affected seven of its municipalities: León, Irapuato, Salamanca, Villagrán, Celaya, Apaseo el Alto and Apaseo el Grande. The purpose of this paper is to shed some light on the nature of this conflict by outlining its main traits. We have posed two guiding questions: Which are the main criminal groups involved in Guanajuato's conflict and what do they pursue? And: Which are the most violent municipalities in Guanajuato in terms of homicides and how do they correlate with the neighbouring states' municipalities of Jalisco and Michoacán including the road network? To answer these questions we have divided this paper into three sections and a concluding part. To begin with, we synthetise the evolution of the main criminal organisations involved in Guanajuato's conflict. Secondly, we compare Guanajuato with its neighbour entities in terms of homicides and rank Jalisco and Michoacán as the main source of violence. In the third section, we correlate the number of homicides on a monthly basis from 2015 to 2019 between León, Irapuato and Salamanca with those municipalities belonging to Jalisco and Michoacán to see if patterns of behaviour - which also considers the road network - can be observed. At the end, we conclude that the violence in Guanajuato can be explained by the confrontation between CJNG and CSRL seeking to take control of oil theft profits.

\section{Evolution of organised crime in Mexico}

Along the Mexican territory, different criminal organisations are carrying out illegal activities and fighting each other to control trade, routes and territory. The government's strategy to fight organised crime since President Felipe Calderón until the first year of Andrés Manuel López Obrador, has focused on incarcerating the main leaders. That

4 Aristigui Noticias, 'Van más de 30 mil homicidios en 2019; Guanajuato, primer lugar en este delito: Durazo’, 17 December 2019.

5 Brenda Yañez, ‘AMLO cerró su primer año con 34,579 homicidios dolosos (4 cada hora)’, Expansión Política, 20 December 2019; Tania L Montalvo, ‘El Cártel Jalisco Nueva Generación creció con EPN hasta ser el más importante del país’, NarcoData, 30 August 2016.

6 Manuel A Botello, 'Comparación Del Precio De La Gasolina, Mexico-USA', Mexico-Maxico, 31 December 2019. 
has triggered a permanent war while new alliances emerge and new leaders replace the ones killed or imprisoned. ${ }^{7}$ There has been nine criminal organisations in the last four decades: 1. El Cartel de Tijuana/Arellano Félix; 2. Cartel de Juárez, 3. Cartel de Sinaloa; 4. Cartel del Golfo; 5. Cartel de los Beltrán Leyva; 6. Cartel de los Zetas; 7. La Familia Michoacana; 8. Los Caballeros Templarios; and 9. Cartel Jalisco Nueva Generación. Along the years, there has been a reshuffling process and shifting of power from one another. New and fewer join ventures have emerged from the original groups; they are now better organised and armed; they are more aggressive and have infiltrated the authorities and the government. They have also improved their products evolving from the traditional drugs like marihuana and cocaine to fentanyl, methamphetamines and heroin. They also controlled the trafficking of people and the theft of oil. Authorities have played a key role since they have assumed full responsibility to fight insecurity. However, there is a growing suspiciousness of a wide synergy between authorities and criminal leaders. Well known communicators and researchers have pointed out that Mexican authorities are bribed by criminal leaders so that they can operate with impunity. Highly respected journalists and social researchers ${ }^{8}$ affirm that authorities are interested in the illegal business to continue and flourish.

Jorge Fernández Menéndez, an expert in security matters, believes that there are 70 criminal groups performing illegal trading in Mexico. However, only two of them can be classified as Cartels: Cartel del Pacífico and Cartel Jalisco Nueva Generación (CJANG). Among the numerous criminal groups identified by the press and local authorities are Cartel de la Unión de Tepito, the H3, Cartel de Tláhuac in Mexico City, Los Viagra in Michoacán, Cartel Independiente in Acapulco and the Rojos and Guerreros Unidos. In Guanajuato, the following names have caught the attention, la Unión de León, Los Carranza, Los Mickeys, Los Puños, Cárteles Unidos and Fuerzas Especiales Grupo Sombra, and the most important, Cartel de Santa Rosa de Lima (CSRL). ${ }^{9}$ We will synthetise the background of the criminal groups involved in Guanajuato's violence also tracked by the U.S. authorities. ${ }^{10}$

$7 \quad$ Felipe Calderon Hinojosa, Los retos que enfrentamos (CDMX: Debate, 2014); Auditoria Superior de la Federación, Evaluación No. 1207 “Política Pública de Seguridad Pública” (CDMX: Cámara de Diputados, 2013); Seguridad y Defensa, ‘Así operan los carteles por el control territorial en el país’, Agencia de Información en Seguridad y Defensa, 25 August 2020; Lorena Moguel, 'Peña admite el fracaso de su gobierno en materia de seguridad', Proceso,14 November 2017.

8 Edgardo Buscalia, Vacíos de poder en México. El camino de México hacia la Seguridad humana (Mexico: Debate, 2013); Jorge Fernández Menéndez and Víctor Ronquillo, De los Maras a los Zetas (Mexico: Debolsillo, 2006); Anabel Hernández, Los señores del narco (Mexico: Grijalbo, 2010); Ricardo Ravelo, Osiel. Vida y Tragedia de un Capo (Mexico: Grijalbo, 2012); Anabel Hernández, El Traidor. El diario del hijo del Mayo (Barcelona: Grijalbo, 2020); María E Garay, Los Policías: una averiguación atropológica (Tlaquepaque, Jalisco: ITESO, 2016); Zona Franca, 'Crimen organizado está infiltrado en siete municipios de Guanajuato', 15 October 2019.

9 Jorge Fernández Menéndez, La nueva guerra. Del Chapo al fentanilo (CDMX: Grijalbo, 2020).

10 Congressional Research Service, Mexico, 'Organized Crime and Drug Trafficking Organizations', CRS Report, 20 December 2019. 


\section{Los Zetas}

This band was founded by deserters from an army elite squad called GAFE (Grupo Aeromóvil de Fuerzas Especiales). Originally, they were hired by the Cartel del Golfo but later they became independent and specialised in oil theft, extortion, kidnapping and human trafficking. They dwelled in the east part of the Gulf of Mexico but have set foot in Ciudad Juárez, Chihuahua. The have established a trade net with Central America and South America, cooperating with elite forces of Guatemala called Kaibiles. As a method to terrorise the population and enemies, they exhibit hung dead bodies from bridges and are known for their extreme brutality. They have created such a bad reputation that even local gangs pretend to be members of Zetas to frighten their victims. According to the press, they set on fire The Royal Casino in 2011 in Monterrey Nuevo León, causing the death of 53 people. They were also responsible for the execution of 72 migrants in 2010 and for 193 dead bodies found in a clandestine pit, all in a place called San Fernando, Tamaulipas. ${ }^{11}$ The Zetas are known for killing those who refuse to work for them, especially illegal migrants, or victims who reject to pay extortions. The Mexican Navy killed one of the founders of this organisation in Coahuila in 2012; his name was Heriberto Lazcano, “El Lasca”. Miguel Ángel Treviño Morales “El Z-40” became the new leader, but was also annihilated by the authorities in 2013. Later, his brother Omar Treviño Morales, "El Z-42" was also detained by the federal forces in 2015. With the elimination the main leaders, the Zetas started to fade away. The Zetas focused on oil theft as one of their key trades, causing losses to Pemex (Mexican Oil and Public Enterprise) calculated in 1.15 billion USD in 2014. It was estimated that the Zetas dominated $40 \%$ of the oil theft in the country, mainly in the federal states of Tamaulipas and Veracruz. ${ }^{12}$ As the Zetas were dispersed, two groups emerged from them, La Vieja Escuela and the Cartel del Noreste. They still command illegal trade in Nuevo León, Tamaulipas, Veracruz, Oaxaca, Tabasco, Campeche and Quintana Roo.

\section{La Familia Michoacana}

This group emerged in the 1980s and was initially moved by religious principles. At the beginning, they worked for the Zetas but broke with them, became enemies and from 2006 to 2010 went to war with one another. They have spent money to finance social projects to gain the sympathy of the population. In 2010, they announced their will to give up their weapons and quit their violent crimes. One of its main leaders, Nazario Moreno González, was allegedly killed but his body was never found. Years later, he showed up and was shot in a fire fight with the police forces in 2014. While facing a downturn, Nazario Moreno created in 2011 a surrogate organisation and gave it the name of "Los Caballeros Templarios”. This new group was initially commanded by José de Jesús Méndez Vargas,

11 Gustavo Castillo García, ‘Mexicanos, los asesinados en San Fernando Tamaulipas’, La Jornada, 13 October 2011.

12 Congressional Research Service, ‘Organized Crime and Drug Trafficking Organizations’. 
"El Chango". The members of this group have received military training and made money out of extortion, abduction, as well as drug trafficking which includes cocaine, heroin, marihuana and methamphetamines. Los Caballeros Templarios lay their vision and mission in Christianity and social justice. Their main purpose is allegedly to protect the people of Michoacán from the Zetas but operate also in other states like Guerrero, the State of Mexico and Mexico City. They are also known for extorting avocado entrepreneurs, lime producers and miners among others. They have settled down in several municipalities of Michoacán like Apatzingán, Abarrotes la Ruana, Tepalcatepec, and also the port of Lázaro Cárdenas from which they have already exported iron to China. ${ }^{13}$

\section{El Cartel Jalisco Nueva Generación (CJNG)}

Nemesio Oseguera Cervantes, known as "El Mencho" is the leader of this group. The CJNG is considered the most powerful syndicate in Mexico and Latin America. According to The Economist, Nemesio Oseguera Cervantes was brought to justice in 1992 in San Francisco, California for selling heroin and spent three years in jail in Texas. He was deported to Mexico and joined the police forces in Jalisco. Later on, he created the Cartel del Milenio. ${ }^{14}$ From the disintegration of this Cartel emerged the CJNG working together with a group named “Los Cunis”, leadered by his brother-in-law Abigael González Valencia, who was captured in February 2015. The CJNG was detected by the Mexican Government in 2011, when they presented themselves in a public video as "Matazetas" (Zetakillers). They tried to gain the sympathy among the population pretending to be marshals who could protect them from the dangerous menace posed by the Zetas. At the beginning, the CJNG established its headquarters in Jalisco, Nayarit and Colima, but has been expanding ever since to 24 federal states like Michoacán, Guanajuato, Veracruz, Guerrero, Morelos, San Luis Potosí, State of Mexico and from 2014 on, Mexico City. In 2016, the CJNG was already in Aguascalientes, Baja California, Oaxaca and Chiapas. It also took control of the Guadalajara-Manzanillo-Lázaro Cárdenas route to ease the export of methamphetamines and the import of chemical precursors from China.

\section{Cartel Santa Rosa de Lima (CSRL)}

On Sunday, 2 August 2020, the Mexican police arrested the leader of the Cartel Santa Rosa de Lima, José Antonio Yépez Ortiz, dubbed as “El Marro”. José Antonio Yépez belonged to "Los Zetas". In 2008, he was captured by the authorities and accused of robbery in the road network. In 2014, he joined the CSRL whose boss by that time was David Roel Figueroa, “El R”. David Roel commanded a group of thugs specialised in oil theft. ${ }^{15}$ By

13 La Jornada, ‘Controlan Caballeros templarios exportación de mineral de hierro’, 03 January 2014.

14 The Economist, 'How will Mexico’s president handle “El Mencho”, a kingpin on the rise?’, 15 August 2020.

15 Manuel Espino Bucio, ‘¿Cuándo y cómo surgió el Cartel de Santa Rosa de Lima?’, El Universal, 05 March 2019; BBC News Mundo, 'El Marro: quién es José Antonio Yépez y por qué su captura puede suponer el fin del cartel de Santa Rosa de Lima en México’, 02 August 2020. 
2017, José Antonio Yépez takes the leadership of the CSRL; he does not only keep stealing gasoline from pipelines, but extended the business to further illegal activities, e.g. drug trafficking, kidnapping and extortion. In that year, the CSRL declares war to CJNG in order to expel it from Guanajuato and put it out of the way from the oil theft business. The main fire encounters have been taking place in León, Irapuato, Celaya, Apaseo el Grande and Apaseo el Alto. There is an underground pipeline transporting fuel to different facilities of PEMEX in the region, all connected to the Salamanca Refinery in Guanajuato.

The CSRL took its name from a place called Santa Rosa de Lima, which belongs to Villagrán where most of the members of this group - aged between 20 and 35 - where born, including relatives of José Antonio Yépez himself. The CSRL group controls illegal trade in Celaya, Salamanca, Santa Cruz, Juventino Rosas, Valle de Santiago and Villagran. ${ }^{16}$ Pundits do not classify the CSRL as a Cartel itself, but as a criminal group which make most of its profit out of oil theft. The CSRL has established a wide net of corruption with local authorities. The CSRL has its followers among the natives who do not hesitate to confront the Federal Police and Army when they penetrate the region to chase the leaders of the CSRL. By any intention of the authorities to step in or detain any of the members of the CSRL, they resort to roadblocks and fires, as well as throwing Molotov cocktails to patrols and other official vehicles. The CSRL has threatened Salamanca's Refinery with bombs several times. ${ }^{17}$ The Army has already spotted a warehouse called "El Hoyo" located in a small town known as San Salvador Torrecillas, where the CSRL hoards large deposits of stolen fuel, lorries and truckloads.

\section{Guanajuato: The most violent entity in 2019}

The organised crime has been expanding along the Mexican territory as a whole. Nevertheless, violence in Guanajuato can be explained by the evolution of three powerful criminal groups coming from the neighbouring states. First of all, the Zetas came from the state of Veracruz and trained the members of CSRL in all illegal trades, but in particular oil theft. As mentioned before, "El Marro”, the former leader of the CSRL, had been himself a member of Zetas. On the other side, the CJNG came from the neighbour state of Jalisco and "Los Caballeros Templarios” came from Michoacán. Once in Guanajuato, the clashes began with the local mobs which tried to defend their territory.

Figure 1 shows the number of homicides in the states of Guanajuato, Jalisco, Michoacán, Querétaro, Aguascalientes and Zacatecas from 1990 to 2018. We can see that Guanajuato used to be a peaceful state along the 1990s and early 2000s, but from 2008 on, homicides started to increase and in 2016, the rate of growth became almost exponential. We correlated the monthly number of homicides from 1990 to 2019 in Guanajuato with those occurring in its neighbour entities depicted in Figure 1. By taking into consideration the

16 Espino Bucio, ‘¿Cuándo y cómo surgió el Cartel de Santa Rosa de Lima?’.

17 On 19 September 2021, the owner of a restaurant in Salamanca was indeed killed by explosion of a bomb hidden in a package (El Financiero, 'Salamanca: esto es lo que sabemos de la explosión que dejó dos muertos', 20 September 2021). 
value of beta $\left(\beta_{2}\right)$ and the proportion of the variance explained by the model $\left(\mathrm{R}^{2}\right)$, we found positive correlations with all Guanajuato's neighbour states, but among the most important were: a) between Guanajuato and Jalisco: $\left(\beta_{2}=0.591 ; \mathrm{R}^{2}=0.8188\right)$ and b) Guanajuato and Michoacán: $\left(\beta_{2}=0.419 ; R^{2}=0.7186\right)$.

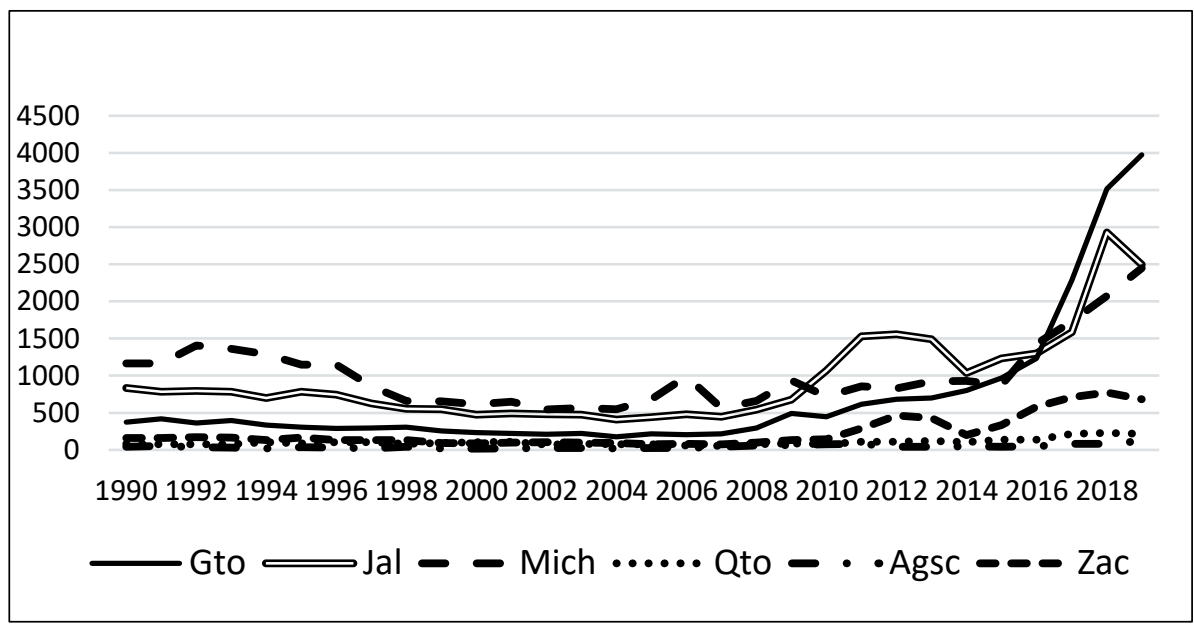

Figure 1: Homicides in Guanajuato, Jalisco, Michoacán, Querétaro, Aguascalientes and Zacatecas

Source: Compiled by Gerardo Reyes based on Instituto Nacional de Geografía e Informática (INEGI), 'Defunciones por homicidios', s. $a$.

Juan Miguel Alcántara Soria found 11 criminal organisations operating in Guanajuato from 2015 to $2019 .{ }^{18}$ David Saucedo ${ }^{19}$ has detected several groups fighting to control geographical areas of Guanajuato depicted in Figure 2; the skull icons represent the hostilities detected by the media. The antagonistic groups are La Unión de León, El Grupo Sombra and Cárteles Unidos. Clashes between the CJNG and El Grupo Sombra have taken place in León; in Pénjamo fights have developed between the CJNG, CSRL, Grupos Sombra and Caballeros Templarios. The shootings have broadened along Irapuato and Salamanca. Saucedo points out that the CJNG has tried to take control over León and Pénjamo since 2013 by invading in the poorest communities, where they recruit new members from the existing gangs and bribe or terrorise the local authorities. Their mission is to expel Los Caballeros Templarios out of the zone. Saucedo rates the clashes between the CJNG and CSRL as the bloodiest and most important in Guanajuato. Fights between the two groups have also occurred in Valle de Santiago, Celaya, Acámbaro, Apaseo el Alto, Apaseo el Grande and San Miguel de Allende. The CJNG has already

18 Juan Miguel Alcántara Soria, ‘Caminos de Guanajuato ¿desde y hasta cuándo violentos’, Milenio, 16 October 2019.

19 David Saucedo, 'Guanajuato bajo asedio criminal: radiografía de la guerra', Periodismo y Opinión Pública, 16 October 2019. 
taken control of Guanajuato’s municipalities of Purísima del Rincón, San Francisco del Rincón, Manuel Doblado, Romita, León, Ocampo and San Felipe, all located in the border with Jalisco. Once there, the CJNG has spread along the most important industrial corridor of Guanajuato and heavy skirmishes have taken place in Irapuato, Salamanca and Celaya. On the other hand, the CSRL commands over the centre and the east of Guanajuato; its sphere of influence covers the municipalities of Villagrán, Juventino Rosas, Comonfort, Apaseo el Alto, Apaseo el Grande, San Miguel de Allende, San José Iturbide, Doctor Mora, San Luis de la Paz, Victoria and Tierra Blanca, most of them located in the border with Querétaro. There were 1,729 homicides registered from January to June 2020 attributable to the war between the CJNG and CSRL. In this context, Proceso, a well-known Mexican magazine, published that between 2016 and 2019 the oil theft amounted to 13.5 million litres of gasoline extracted directly from the underground pipelines belonging to PEMEX, the Mexican State Oil Company. ${ }^{20}$

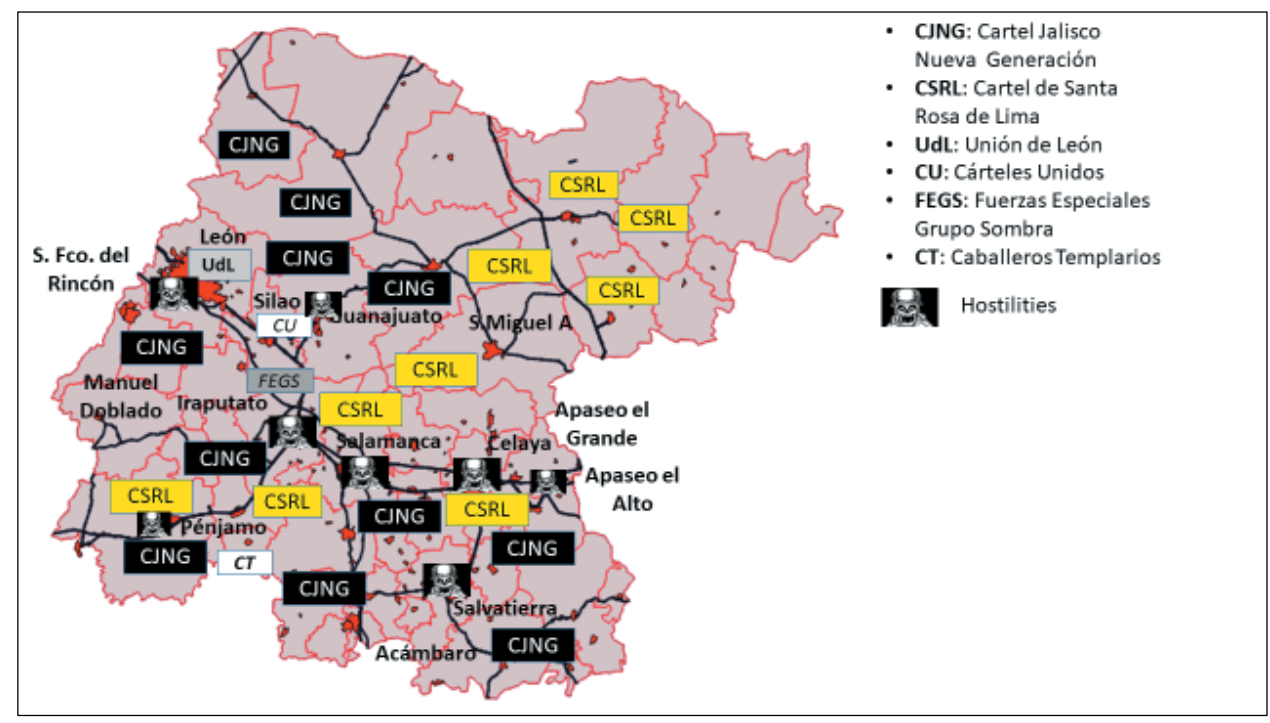

Figure 2: Fighting groups and strategic areas in Guanajuato

Source: Compiled by Gerardo Reyes based on Saucedo, 'Guanajuato bajo asedio criminal'.

\section{Homicides: correlation among the municipalities}

Jorge Fernández asserts that there are three main pathways by which illegal products are moved from South to North by the criminal organisations: a) along the Gulf of Mexico; b) the Pacific shore; and c) through the centre of the Caribbean. ${ }^{21}$ The Caribbean route

\footnotetext{
20 Verónica Espinosa, 'Huachicoleo en Guanajuato: roban 13.5 millones de litros de gasolina en tres años', Proceso, 01 January 2019.

21 Menéndez, 'La nueva guerra'.
} 
crosses the state of Guanajuato connecting several municipalities. If we track violence by correlating roads and municipalities based on the number of homicides, we could throw some light on the modus operandi of the criminal groups. To start with, 11,580 murders were reported from 2015 to 2019 in 18 municipalities located in the states of Jalisco, Guanajuato and Michoacán. ${ }^{22}$ From that tally, the share of the municipalities mentioned were distributed as follows: Guadalajara (13\%) and León (13\%); followed by Tlaquepaque (9\%) and Irapuato (8\%); the threesome: Tlajomulco de Zúñiga (7\%), Morelia (7\%) and Salamanca (7\%). In a less dangerous level we found: Celaya (6\%), Tonalá (5\%) and Zamora (5\%). The municipalities with the least share in this analysis were: Pénjamo (3\%), Silao (3\%), Salvatierra (3\%), El Salto (3\%), Acámbaro (2\%), Sahuayo (2\%), Lagos de Moreno (2\%) and La Piedad (1\%).

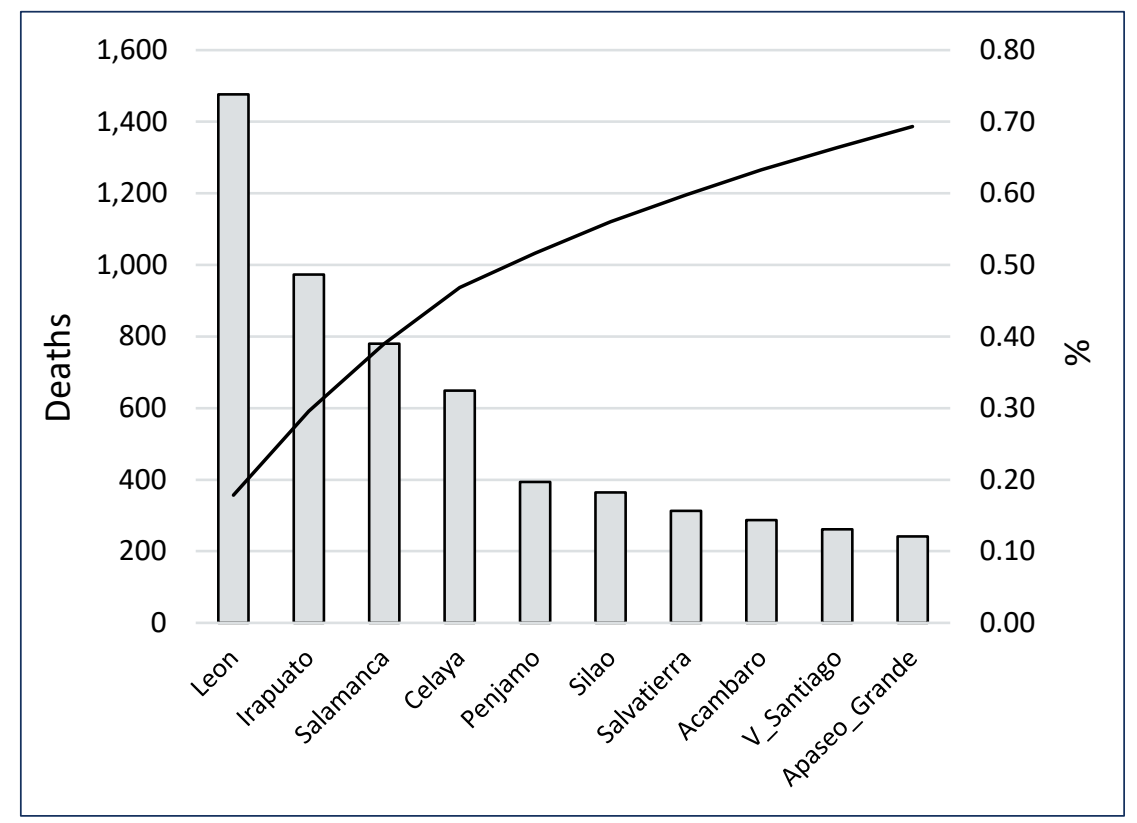

Figure 3: Guanajuato: homicides 2015-2019

Source: Compiled by Gerardo Reyes based on SESNSP, 'Datos Abiertos de Incidencia Delictiva'.

Figure 3 shows that 70\% of the homicides committed in Guanajuato from 2015 to 2019 took place on 10 municipalities out of which, three are accountable for $40 \%$ of the murders: León, Irapuato and Salamanca. Table 1 displays the number of homicides per 100,000 people. León ranks in the first place with 128 in 2015 with a downward trend. However, in the rest of the municipalities we noticed an upward tendency. Among the most noticeable are Apaseo el Grande which goes from 15 in 2015 to 124 in 2019, an increment of 825\% or an annual average rate (Y-AVG) of 52.56\%; Celaya jumped (+) 500\% from 11 to 56 homicides

22 Secretariado Ejecutivo del Sistema Nacional de Seguridad Pública (SESNSP), 'Datos Abiertos de Incidencia Delictiva', s. a. 
per 100,000 people, or an equivalent of 38.47 Y-AVG; Valle de Santiago, from 17 to 77, +450\%, 35.27 Y-AVG; Salvatierra, from 31 to 122, +400\%, 31.52 Y-AVG and Salamanca, from 33 to 122, +360\%, 29.88 Y-AVG. Those numbers suggest that violence soared from 2015 on and rebounded in 2017, the year in which the price increase in gasoline took place.

Table 1: Guanajuato: number of homicides per 100,000 people

\begin{tabular}{|l|c|c|c|r|r|r|}
\hline & $\mathbf{2 0 1 5}$ & $\mathbf{2 0 1 6}$ & $\mathbf{2 0 1 7}$ & $\mathbf{2 0 1 8}$ & $\mathbf{2 0 1 9}$ & Y-AVG \\
\hline León & 128 & 126 & 125 & 123 & 120 & -1.28 \\
\hline Irapuato & 26 & 32 & 57 & 59 & 75 & 23.59 \\
\hline Salamanca & 33 & 29 & 25 & 132 & 122 & 29.88 \\
\hline Celaya & 11 & 13 & 16 & 55 & 56 & 38.47 \\
\hline Pénjamo & 48 & 64 & 59 & 120 & 125 & 21.98 \\
\hline Silao & 25 & 31 & 26 & 66 & 54 & 16.65 \\
\hline Salvatierra & 31 & 30 & 39 & 128 & 122 & 31.52 \\
\hline Acámbaro & 36 & 34 & 33 & 96 & 71 & 14.54 \\
\hline V. Santiago & 17 & 28 & 18 & 53 & 77 & 35.27 \\
\hline A. el Grande & 15 & 15 & 19 & 96 & 124 & 52.56 \\
\hline
\end{tabular}

Source: Compiled by Gerardo Reyes based on SESNSP, 'Datos Abiertos de Incidencia Delictiva'.

We correlated monthly homicides between Guanajuato's top three municipalities and the neighbouring municipalities of Jalisco and Michoacán from 2015 to 2019. We also took into consideration the distance between the municipalities and the time it takes to drive from one another according to google maps.

In the first regression model the dependent variable was León and the independent variables were Tlaquepaque, Tlajomulco de Zúñiga, Tonalá, Zamora and El Salto.

$$
\hat{y}_{\text {Leon }}=\beta_{0}+\beta_{1} x_{\mathrm{SP} \_ \text {Tlaque }}+\beta_{2} x_{\mathrm{T}_{\text {_dZuniga }}}+\beta_{3} x_{\text {Tonalá }}+\beta_{4} x_{\text {Zamora }}+\beta_{5} x_{\text {El_Salto }}
$$

Table 2: Regression parameters

\begin{tabular}{|c|c|c|c|c|c|c|}
\hline Coefficients & Estimate & Std. Error & t value & $\operatorname{Pr}(>|t|)$ & Sig & Dist/Time \\
\hline (Intercept) & 1.6586 & 2.1572 & 0.769 & 0.44531 & & \\
\hline SP_Tlaque & 0.4247 & 0.1389 & 3.058 & 0.00346 & $* *$ & 238 km; 2:40 h \\
\hline T_dZuniga & 0.4406 & 0.1509 & 2.921 & 0.00509 & $* *$ & $242 \mathrm{~km}: 2: 58 \mathrm{~h}$ \\
\hline Tonala & 0.9052 & 0.2001 & 4.524 & $3.37 \mathrm{e}-05$ & $* * *$ & $207 \mathrm{~km} ; 2: 22 \mathrm{~h}$ \\
\hline Zamora & 0.4821 & 0.1493 & 3.230 & 0.00211 & $* *$ & $169 \mathrm{~km} ; 2: 35 \mathrm{~h}$ \\
\hline El_Salto & -0.7486 & 0.3238 & -2.312 & 0.02463 & $*$ & $212 \mathrm{~km} ; 2: 35 \mathrm{~h}$ \\
\hline \multicolumn{7}{|c|}{ Signif. codes: 0 ‘***’ 0.001 ‘**’ 0.01 ‘*’ 0.05 ‘’ $0.1^{\prime}$ ‘’ 1} \\
\hline \multicolumn{7}{|c|}{$\begin{array}{l}\text { Residual standard error: } 6.119 \text { on } 54 \text { degrees of freedom } \\
\text { Multiple R2: } 0.7192 \text {, Adjusted R²: } 0.6932 \\
\text { F-statistic: } 27.66 \text { on } 5 \text { and } 54 \text { DF, p-value: } 9.029 \text { e-14 }\end{array}$} \\
\hline
\end{tabular}

Source: Compiled by Gerardo Reyes based on SESNSP, 'Datos Abiertos de Incidencia Delictiva'. 
Table 2 displays the model's results which proved to be significant based on p-values and the adjusted $\mathrm{R}^{2}$ (almost 0.7 ). The highest correlation coefficient turned to be with Tonalá which is located $207 \mathrm{~km}$ away from León or 2:22 h drive. For every homicide committed in Tonalá $\left(\beta_{3}\right), 0.9052$ homicides occurred in Leon. Secondly, for every homicides taking place in Zamora $\left(\beta_{4}\right)$, there were 0.4821 homicides in León. Zamora is $169 \mathrm{~km}$ away from León or 2:35 h drive. San Pedro de Tlaquepaque $\left(\beta_{1}\right)$ and Tlajomulco de Zuñiga $\left(\beta_{2}\right)$ have similar beta values as well as distance and driving time. We noticed an inverse relationship between the distance time and the beta value, thus, the smaller the distance time factor, the higher the value of beta. Tlajomulco de Zuñiga, Tonala and Tlaquepaque - all of them belonging to Jalisco - are on the road network that conveys to León. On the other side, Zamora, which is located in Michoacán, has also a direct connection with León.

We proceeded analogously with Irapuato. In model 2, the dependent variable represents the homicides happening in Irapuato and the independent variables, those homicides occurring in Guadalajara and Tlaquepaque.

$$
\hat{y}_{\text {Irapuato }}=\beta_{0}+\beta_{1} x_{\text {Guadala }}+\beta_{2} x_{\text {SP_Tlaquepaque }}
$$

Table 3: Regression parameters

\begin{tabular}{|c|c|c|c|c|c|c|}
\hline Coefficients & Estimate & Std. Error & t value & $\operatorname{Pr}(>|t|)$ & Sig & Dist/Time \\
\hline (Intercept) & -5.7663 & 2.2457 & -2.568 & 0.01288 & $*$ & \\
\hline Guadala & 0.4052 & 0.1263 & 3.209 & 0.00219 & ** & $245 \mathrm{~km} ; 3: 0 \mathrm{~h}$ \\
\hline SP_Tlaque & 0.7122 & 0.1490 & 4.780 & $1.27 \mathrm{e}-05$ & $* * *$ & $239 \mathrm{~km} ; 2: 5 \mathrm{~h}$ \\
\hline \multicolumn{7}{|c|}{ 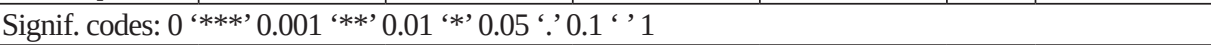 } \\
\hline \multicolumn{7}{|c|}{$\begin{array}{l}\text { Residual standard error: } 7.225 \text { on } 57 \text { degrees of freedom } \\
\text { Multiple R': } 0.7023 \text {, Adjusted R²: } 0.6918 \\
\text { F-statistic: } 67.22 \text { on } 2 \text { and } 57 \text { DF, p-value: } 1.011 \text { e-15 }\end{array}$} \\
\hline
\end{tabular}

Source: Compiled by Gerardo Reyes based on SESNSP, 'Datos Abiertos de Incidencia Delictiva'.

Table 3 displays the model's parameters which proved to be significant based on p-values and an adjusted $\mathrm{R}^{2}$ of 0.6918 . The highest correlation based on a p-value turned to be with San Pedro de Tlaquepaque $\left(\beta_{2}\right)$; for every homicide reported in this municipality, 0.7122 violent murders took place in Irapuato. Tlaquepaque belongs to Jalisco and it is $239 \mathrm{~km}$ away from Irapuato or almost 3 h drive. Secondly, Guadalajara had a significant correlation; it is $245 \mathrm{~km}$ away or 2:5 h drive. Again, we also noticed in this model an inverse relationship between distance time and the beta value. That matches with the fact that there is a direct road that connects Guadalajara - San Pedro de Tlaquepaque - Jalisco-Irapuato.

Finally, we run a correlation model with Salamanca representing the dependent variable and Guadalajara, Tonalá, Zamora and Lagos de Moreno as the independent variables. 


$$
\hat{y}_{\text {Salamanca }}=\beta_{0}+\beta_{1} x_{\text {Guadala }}+\beta_{2} x_{\text {Tonala }}+\beta_{3} x_{\text {Zamora }}+\beta_{4} x_{\mathrm{L}_{\text {ddMoreno }}}
$$

Table 4: Regression parameters

\begin{tabular}{|c|c|c|c|c|c|c|}
\hline Coefficients & Estimate & Std. Error & t value & $\operatorname{Pr}(>|t|)$ & Sig & Dist/Time \\
\hline (Intercept) & -7.7327 & 2.2234 & -3.478 & 0.00101 & $* *$ & \\
\hline Guadala & 0.5122 & 0.0709 & 7.225 & $1.78 \mathrm{e}-09$ & $* * *$ & 264 km; 3:14 h \\
\hline Tonala & 0.3259 & 0.1604 & 2.032 & 0.04712 & $*$ & 252 km; 3:02 h \\
\hline Zamora & 0.3712 & 0.1200 & 3.093 & 0.00313 & $* *$ & 163 km; 2:03 h \\
\hline L_dMoreno & 0.7296 & 0.2184 & 3.340 & 0.00152 & $* *$ & 136 km; 1:4 h \\
\hline \multicolumn{7}{|c|}{ Signif. codes: 0 ‘***’ $0.001^{\prime * * * ’} 0.01^{\prime * * ’} 0.05$ ‘’0.1 ‘’1 } \\
\hline \multicolumn{7}{|c|}{$\begin{array}{l}\text { Residual standard error: } 4.924 \text { on } 54 \text { degrees of freedom } \\
\text { Multiple } R^{2}: 0.8024 \text {, Adjusted R²: } 0.7842 \\
\text { F-statistic: } 43.87 \text { on } 5 \text { and } 54 \text { DF, p-value: }<2.2 \mathrm{e}-1\end{array}$} \\
\hline
\end{tabular}

Source: Compiled by Gerardo Reyes based on SESNSP, 'Datos Abiertos de Incidencia Delictiva'.

Table 4 displays the model's parameters which proved to be significant based on p-values and adjusted $\mathrm{R}^{2}$ of 0.7842 . Guadalajara presented the most significant p-value and a beta of 0.5122 ; this municipality is located $264 \mathrm{~km}$ away from Salamanca or a 3:14 h drive. Lagos de Moreno had a p-value of 0.00152 and a beta of 0.7296. Lagos de Moreno is $136 \mathrm{~km}$ away from Salamanca or 1:40 h drive. Zamora had a beta of 0.3712 and a p-value of 0.00313. Zamora belongs to Michoacán and is $163 \mathrm{~km}$ away from Salamanca or 2:03 h drive. Tonalá presented the weakest correlation with a p-value of 0.04712 . Tonalá is $252 \mathrm{~km}$ away from Salamanca or 3:02 h drive. Except for the case of Guadalajara, the inverse relationship between the value of beta and the distance time factor remained.

\section{Conclusions}

We can answer the guiding questions posed at the beginning as follows. Three criminal groups have arrived in Guanajuato to take control of oil theft: CJNG, the remainings of La Familia Michoacana or Los Caballeros Templarios and Los Zetas. A fourth group flourishes in Guanajuato with close connections with Los Zetas: CSRL. There is evidence that this invasion started in 2010, but it became more intense from 2015 onwards. It seems that the rise of gasoline price in 2017 coincides with the spike of homicides that year. Oil theft turned into a high profitable business and unleashed a war among these criminal groups, all seeking to control that trade. The corridor Salamanca-Irapuato-Leon turned into a dangerous pathway. The hypothesis that binds the road network with violence becomes relevant. The regression model shed some light on a regional problem involving the neighbouring states of Jalisco and Michoacán as the main factors explaining the increase of violence in Guanajuato from 2015 onwards. The inverse relationship between the distance time factor and the value of beta in the regression clearly correlates the municipalities which present the highest levels of homicides, suggesting the existence of a common modus operandi of the criminal groups involved. Thus, federal roads have 
become a key mean of transportation of oil theft and further criminal trades, a fact that should be considered by the authorities in order to implement a peace strategy in Guanajuato.

\section{References}

Alcántara Soria, Juan Miguel, ‘Caminos de Guanajuato ¿desde y hasta cuándo violentos’. Milenio, 16 October 2019. Online: www.milenio.com/opinion/juan-miguel-alcantara-soria/ instinto-de-conservacion/caminos-de-guanajuato-desde-y-hasta-cuando-violentos

Aristigui Noticias, 'Van más de 30 mil homicidios en 2019; Guanajuato, primer lugar en este delito: Durazo’, 17 December 2019. Online: https://aristeguinoticias.com/1712/mexico/ este-2019-van-mas-de-30-mil-homicidios-guanajuato-es-primer-lugar-en-este-delitodurazo/

Auditoria Superior de la Federación, Evaluación No. 1207 "Política Pública de Seguridad Pública”. CDMX: Cámara de Diputados, 2013.

BBC News Mundo, 'El Marro: quién es José Antonio Yépez y por qué su captura puede suponer el fin del cartel de Santa Rosa de Lima en México’, 02 August 2020. Online: www.bbc. com/mundo/noticias-america-latina-53631953

Botello, Manuel A, ‘Comparación Del Precio De La Gasolina, Mexico-USA'. Mexico-Maxico, 31 December 2019. Online: www.mexicomaxico.org/Voto/GasolMexUSA.htm

Buscalia Edgardo, Vacíos de poder en México. El camino de México hacia la Seguridad humana. Mexico: Debate, 2013.

Castillo García, Gustavo, 'Mexicanos, los asesinados en San Fernando Tamaulipas'. La Jornada, 13 October 2011. Online: www.jornada.com.mx/2011/10/13/politica/007n1pol

Calderón Hinojosa, Felipe, Los retos que enfrentamos. CDMX: Debate, 2014.

Congresional Research Service, Mexico, 'Ogranized Crime and Drug Trafficking Organizations’. CRS Report, 20 December 2019. Online: https://crsreports.congress.gov/

Espino Bucio, Manuel, ‘¿Cuándo y cómo surgió el Cartel de Santa Rosa de Lima?’. El Universal, 05 March 2019. Online: www.eluniversal.com.mx/nacion/seguridad/cuando-ycomo-surgio-el-cartel-de-santa-rosa-de-lima

Espinosa, Verónica, ‘Huachicoleo en Guanajuato: roban 13.5 millones de litros de gasolina en tres años’. Proceso, 01 January 2019. Online: www.proceso.com.mx/reportajes/2019/1/1/ huachicoleo-en-guanajuato-roban-135-millones-de-litros-de-gasolina-en-tres-anos-217903. html

El Financiero, 'Salamanca: Esto es lo que sabemos de la explosión que dejó dos muertos', 20 September 2021. Online: www.elfinanciero.com.mx/estados/2021/09/20/salamancaesto-es-lo-que-sabemos-sobre-la-explosion-que-dejo-2-muertos/

Garay, María E, Los Policías: una averiguación atropológica (Tlaquepaque, Jalisco: ITESO, 2016). Online: https://doi.org/10.2307/j.ctvjk2wt8

Hernández, Anabel, Los señores del narco. Mexico: Grijalbo, 2010.

Hernández, Anabel, El Traidor. El diario del hijo del Mayo. Barcelona: Grijalbo, 2020. 
Instituto Nacional de Geografía e Informática (INEGI), 'Defunciones por homicidios', s. a. Online: www.inegi.org.mx/sistemas/olap/proyectos/bd/continuas/mortalidad/ defuncioneshom.asp?s=est

La Jornada, ‘Controlan Caballeros templarios exportación de mineral de hierro’, 03 January 2014. Online: www.jornada.com.mx/2014/01/03/politica/005n1pol

Menéndez, Jorge Fernández, La nueva guerra. Del Chapo al fentanilo. CDMX: Grijalbo, 2020. Menéndez, Jorge Fernández and Víctor Ronquillo, De los Maras a los Zetas. Mexico: Debolsillo, 2006.

Moguel, Lorena, 'Peña admite el fracaso de su gobierno en materia de seguridad'. Proceso, 14 November 2017. Online: www.noticiaspv.com.mx/pena-admite-el-fracaso-de-sugobierno-en-materia-de-seguridad/

Montalvo, Tania L, ‘El Cártel Jalisco Nueva Generación creció con EPN hasta ser el más importante del país’. NarcoData, 30 August 2016. Online: https://narcodata.animalpolitico. com/jalisco-nueva-generacion-actualmente-el-cartel-mas-poderoso-en-mexico/

Ravelo, Ricardo, Osiel. Vida y Tragedia de un Capo. Mexico: Grijalbo, 2012.

Saucedo, David, ‘Guanajuato bajo asedio criminal: radiografía de la guerra’. Periodismo y Opinión Pública, 16 October 2019. Online:https://poplab.mx/article/ Guanajuatobajoasediocriminalradiografiadelaguerra

Seguridad y Defensa, 'Así operan los carteles por el control territorial en el país’. Agencia de Información en Seguridad y Defensa, 25 August 2020. Online: https://seguridadydefensa. mx/nacionales/asi-operan-los-carteles-por-el-control-territorial-en-el-pais/

Secretariado Ejecutivo del Sistema Nacional de Seguridad Pública (SESNSP), 'Datos Abiertos de Incidencia Delictiva’, s. a. Online: www.gob.mx/sesnsp/acciones-y-programas/datosabiertos-de-incidencia-delictiva

The Economist, 'How will Mexico’s president handle “El Mencho”, a kingpin on the rise?’, 15 August 2020. Online: www.economist.com/the-americas/2020/08/15/how-willmexicos-president-handle-el-mencho-a-kingpin-on-the-rise

Yañez, Brenda, 'AMLO cerró su primer año con 34,579 homicidios dolosos (4 cada hora)'. Expansión Política, 20 December 2019. Online: https://politica.expansion.mx/ mexico/2019/12/20/amlo-cierra-su-primer-ano-con-34-579-homicidios-dolosos-4-cadahora

Zona Franca, 'Crimen organizado está infiltrado en siete municipios de Guanajuato’, 15 October 2019. Online: https://zonafranca.mx/seguridad/crimen-organizado-esta-infiltrado-en-sietemunicipios-de-guanajuato/ 